\title{
ANALISIS STRATEGI PENGEMBANGAN UKM AMPLANG BULAN- BULAN AZZAHRA TRK DI KOTA TARAKAN
}

\section{DEVELOPMEN STRATEGY ANALYSIS OF SMALL AND MICRO BUSINESS AMPLAM BULAN-BULAN AZZAHRA TRK IN TARAKAN CITY}

\author{
Meylin Rahmawati \\ Universitas Borneo Tarakan
}

\begin{abstract}
Abstrak: Usaha amplang ikan bulan-bulan Azzahra di Kota Tarakan merupakan salah satu usaha rumah tangga yang memproduksi amplang ikan bulan-bulan. Tujuan dari penelitian ini untuk menganalisis strategi pengembangan amplang ikan bulan-bulan Azzahra. Berdasarkan hasil pembobotan menggunakan alat analisis SWOT diperoleh skor terbobot dari faktor internal dan eksternal. Total nilai yang diperoleh dari faktor internal yaitu strength 2,23 dan weakness 1,05 dan dari faktor eksternal yaitu opportunities 1,28 dan threats 0,98. Hal tersebut menunjukkan faktor peluang yang dimiliki oleh UKM Amplang Ikan Bulan-Bulan Azzahra lebih besar dari ancaman. Dapat disimpulkan bahwa strategi pengembangan yang dapat digunakan yaitu strategi SO (Strength - Opportunities) dengan menggunakan kekuatan yang dimiliki untuk memanfaatkan peluang yang ada.
\end{abstract}

Kata Kunci : SWOT, UKM Azzahra, Usaha Amplang

Abstract : Bulan-bulan fish Amplang business of Azzahra in Tarakan City represent one of domestic business producing amplang of months fish. This research was aimed to analyse the development strategy of amplang of bulan-bulan fish of Azzahra. Pursuant to wight result use the analyzer SWOT obtained a wight score from internal factor and eksternal. Total value obtained from internal factor that is strength 2,23 and weakness 1,05 and from factor eksternal that is opportunities 1,28 and Threats 0,98. The mentioned show the opportunity factor owned by UKM Amplang of Bulan-bulan Fish of Months Azzahra is bigger than the Threat. Inferential that development strategy which can be used is SO Strategy (Strength Opportunities) by using Strength owned to exploit the existing Opportunity.

Keywords SWOT, UKM Azzahra, Amplang Business

\section{LATAR BELAKANG}

Menurut Undang - undang Nomor 20 Tahun 2008, pengertian usaha mikro, kecil, dan menengah (UMKM) di Indonesia adalah usaha ekonomi produktif yang berdiri sendiri, yang dilakukan oleh orang perseorangan atau badan yang bukan anak perusahaan atau cabang perusahaan yang dimiliki, dikuasai, atau menjadi bagian baik langsung 
maupun tidak langsung. Usaha mikro, kecil, dan menengah merupakan perkumpulan masyarakat yang melihat potensi alam dan sumber daya manusia sebagai suatu usaha baru untuk melengkapi kebutuhan perekonomiannya atau menguatkan perekonomiannya dan bagi perekonomian Indonesia. Pemberdayaan usaha mikro, kecil, dan menengah merupakan langkah strategis dalam meningkatkan dan memperkuat dasar kehidupan perekonomian dari sebagian besar rakyat Indonesia, khususnya melalui penyediaan lapangan kerja dan mengurangi kesenjangan dan tingkat kemiskinan (Afiffudin, 2010:180). Dengan demikian upaya untuk memberdayakan usaha mikro, kecil, dan menengah harus terencana, sistematis, dan menyeluruh.

Sektor usaha kecil dan menengah saat ini merupakan sektor yang sangat diperhatikan oleh pemerintah, hal ini terbukti dengan seriusnya perhatian pemerintah dalam mengembangkan Usaha Mikro Kecil Menengah (UMKM) di Indonesia. Hal ini dinilai wajar karena ternyata usaha kecil dan menengah sangat berpengaruh terhadap perekonomian negara, bahkan lebih dari separuh penduduk Indonesia berpenghasilan dari sektor ini.

Pemberdayaan Usaha Mikro Kecil Menengah (UMKM) sangat penting dan strategis dalam mengantisipasi kedudukan perekonomian kedepan terutama dalam memperkuat struktur perekonomian nasional. Adanya krisis perekonomian nasional seperti sekarang ini sangat mempengaruhi stabilitas nasional, ekonomi dan politik, yang imbasnya berdampak pada kegiatan-kegiatan usaha besar yang semakin terpuruk, sementara Usaha Mikro Kecil Menengah serta Koperasi relatif masih dapat mempertahankan kegiatan usahanya (Adam dkk, 2016). Ketika terjadi krisis ekonomi 1998, hanya sektor UMKM yang bertahan dari kolapsnya ekonomi, sementara sektor yang lebih besar justru tumbang oleh krisis. Krisis ini telah mengakibatkan kedudukan posisi pelaku sektor ekonomi berubah. Usaha besar satu persatu pailit karena bahan baku impor meningkat secara drastis, biaya cicilan utang meningkat sebagai akibat dari nilai tukar rupiah terhadap dollar yang menurun dan berfluktuasi. Sektor perbankan yang ikut terpuruk turut memperparah sektor industri dari sisi permodalan. Banyak perusahaan yang tidak mampu lagi meneruskan usaha karena tingkat bunga yang tinggi. Berbeda dengan UMKM yang sebagian besar tetap bertahan, bahkan cenderung bertambah (Departemen Koperasi, 2008).

Sektor Usaha Mikro Kecil dan Menengah (UMKM) ini mampu menyerap tenaga kerja cukup besar dan memberi peluang bagi UMKM untuk berkembang dan bersaing dengan perusahaan yang lebih cenderung menggunakan modal besar (capital intensive). Eksistensi UMKM memang tidak dapat diragukan lagi karena terbukti mampu bertahan dan menjadi roda penggerak ekonomi, terutama pasca krisis ekonomi. Disisi 
lain, UMKM juga menghadapi banyak sekali permasalahan, yaitu terbatasnya modal kerja. Sumber Daya Manusia yang rendah, dan minimnya penguasaan ilmu pengetahuan serta teknologi (Sudaryanto dan Hanim, 2002). Usaha Mikro Kecil Menengah (UMKM) juga sulit berkembang dikarenakan kompetensi pemilik usaha yang masih kurang dalam mengelola usaha, biasanya mereka berjalan apa adanya atau usaha turun temurun dari warisan orang tua, sehingga apabila dinilai perkembangan usaha mereka hanya terbatas menutupi kebutuhan hidup pemiliknya tanpa berusaha untuk mengembangkannya. Sehingga gunanya pembuatan Laporan Studi Kelayakan Bisnis ini dimaksudkan untuk menilai layak tidaknya dalam mengembangkan investasi, layak tidaknya eksistensi akan usaha yang dilakukan berdasarkan aspek yang terkait.

Kota Tarakan adalah salah satu kota di Provinsi Kalimantan Utara yang letaknya strategis sehingga memiliki potensi sumber daya terbaharui khususnya potensi sumber daya perikanan. Salah satunya yaitu ikan bulan-bulan. Ikan yang memiliki nama Megalops Cyprino (Ides Broussonet, 1982) merupakan salah satu produk perikanan yang sering dikonsumsi masyarakat. Selain dapat dijual dalam keadaan mentah atau dibekukan, ikan bulan-bulan dapat dijual dalam bentuk produk olahan. Salah satu strategi yang apat dilakukan untuk meningkatkan harga jual komoditi perikanan adalah dengan mengolahnya terlebih dahulu menjad produk siap konsumsi. Di Kota Tarakan terdapat industri kecil yang mengolah ikan bulan-bulan menjadi produk olahan amplang yang sekaligus merupakan oleh-oleh khas Kota Tarakan dan berkontribusi terhadap pendapatan daerah.

\section{RUMUSAN MASALAH}

Berdasarkan latar belakang tersebut maka rumusan masalah yang akan diteliti adalah:

1. Potensi apa saja yang dimiliki UKM Amplang Bulan-bulan yang dapat dikembangkan menjadi UKM yang lebih berkembang lagi?

2. Kendala apa saja yang dihadapi pihak pengelola UKM Amplang Bulan-bulan dalam upaya pengembangan UKM?

3. Bagaimanakah strategi pengembangan yang cocok untuk UKM Amplang Bulan-bulan?

\section{TUJUAN PENELITIAN}

Sesuai dengan permasalahan yang telah dirumuskan, tujuan penelitian adalah sebagai berikut :

1. Untuk mengetahui potensi yang dimiliki oleh UKM Amplang Bulan-bulan yang kemudian dapat dikembangkan menjadi UKM yang lebih maju.

2. Untuk mengetahui kendala yang dihadapi pihak pengelola UKM Amplang Bulan-bulan dalam upaya pengembangan UKM. 
3. Membuat strategi pengembangan UKM Amplang Bulan-bulan di Kota Tarakan.

\section{TINJAUAN EMPIRIS}

Pada bagian ini memuat tentang penelitian-penelitian yang telah dilakukan sebelumnya sebagai studi empiris yang mendasari pemikiran penulis dan menjadi pertimbangan dalam penyusunan skripsi ini, antara lainsebagai berikut:

1. Sutinah Made dengan judul Strategi Pengembangan Produk Abon Ikan Kering untuk Mengakses Pasar Internasional, metode kualitatif deskriptif, observasi, dokumentasi, wawancara dan analisis SWOT dengan hasil tingkat kelayakan usaha pengolahan produk abon ikan kering >1,ini mengindikasikan bahwa usaha tersebut layak dikembangkan begitupun dengan nilai IRR sebesar 23,026\% menjelaskan bahwa usaha abon ikan kering layak untuk dikembangkan karena nilai yang diperoleh ini> nilai tingkat suku bunga bank yang berlaku saaat ini, yaitu sebesar 14\%. Peran pemerintah terhadap bantuan modal pada usaha abon ikan kering belum ada, namun sebagian kecil dari kelompok perempuan tersebut sudah mendapat bantuan alat produksi, tapi belum merata pada semua kelompok dan alat tersebut ada juga tidak sesuai dengan kebutuhan kelompok. Pola kemitraan industri dan lembaga keuangan belum berperan dalam permodalan usaha pengolahan produk abon ikan kering, sehingga kelompok usaha tersebut susah berkembang, hanya saja dengan adanya program Dikti melalui program IbIKK ini dapat dimanfaatkan untuk pengembangan kelompok melalui kemitraan usaha dengan laboratorium Agribisnis Fakultas Ilmu Perikanan dan Kelautan Universitas Hasanuddin.

2. Nurmaningsih(Ukrindo,Jakarta,201 0) dengan judul Strategi Pengembangan Usaha Pengolahan Ikan (Studi Kasus Pengolahan Abon Ikan di KUB Hurip Mandiri menggunakan metode Kualititatif deskriptif,observasi, dokumentasi wawancara dan analisis SWOT dengan hasil Unit usaha KUB Hurip Mandiri berdasarkan aspek keuangan memiliki kekayaan (profitable) dan kemampuan (feasible) mengembalikan cicilan kredit PBB usaha hanya 8,5 Bulan PBP hanya 4,5 bulan lebih pendek dari jangka waktu pengembalian kredit selama 2 (dua) tahun di Bank Jabar. Profit margin dalam setahun sebesar $15,32 \%$ dalam masa asumsi proyek 5 (lima) tahiun, pada tingkat suku bunga $10 \%$ per tahun. memiliki net ratio $\mathrm{B} / \mathrm{C}$ sebesar $5,81 \%(>1)$ an NVP sebesar Rp. 35.392.844,- dengan nilai IRR 153,13\% (> discount rate) meskipun tingkat suku bunga mencapai 153,38\%. Bobot nilai IFAS pada besaran 2,70. Memiliki arti bahwa faktor internal dalam 
posisi cukup kuat dalam menjalankan kegiatan usahanya. Nilai EFAS pada besaran 2,60 memiliki arti bahwa keadaan ekstenal diluar unit usaha dalam kategori sedang. KUB Hurip Mandiri memiliki kemampuan merespon peluang dan mengurangi ancaman yang akan terjadi.

3. Arif Rahmana (Universitas Wydiatama, Bandung 2012) dengan judul Strategi Pengembangan Usaha Kecil Menengah Sektor Industri Pengolahan menggunakan metode kualitatif deskriptif, obeservasi dokumentasi, wawncara dan analisis SWOT dengan strategi yang tepat adalah strategi S-T (Strength - Threats), atau dikenal juga dengan istilah strategi diversifikasi, maka sebaiknya UKM melakukan diversifikasi produk presisi dengan menggunakan teknologi CNC, CAD, dan CAM. Dengan dipercayanya sebagai subkontraktor industri-industri besar, membuat kesempatan yang sangat luas untuk mengembangkan spare part mesin-mesin industri, dengan kualitas yang tidak kalah bersaing dengan produk impor karena pada dasarnya UKM tersebut mempunyai teknologi yang canggih dalam proses produksinya, didukung pula dengan kemampuan UKM itu sendiri membuat produkproduk yang presisi.

\section{DEFINISI KONSEP}

\section{$\underline{\text { Usaha Kecil Menengah }}$}

UKM merupakan suatu bentuk usaha kecil masyarakat yang pendiriannya berdasarkan inisiatif seseorang. Sebagian besar masyarakat beranggapan bahwa UKM hanya menguntungkan pihak-pihak tertentu saja. Padahal sebenarnya UKM sangat berperan dalam mengurangi tingkat pengangguran yang ada diIndonesia. UKM dapat menyerap banyak tenaga kerja Indonesia yang masih mengganggur. Selain itu UKM telah berkontribusi besar pada pendapatan daerah maupun pendapatan negara Indonesia.

UKM juga memanfatkan berbagai Sumber Daya Alam yang berpotensial di suatu daerah yang belum diolah secara komersial. UKM dapat membantu mengolah Sumber Daya Alam yang ada di setiap daerah. Hal ini berkontribusi besar terhadap pendapatan daerah maupun pendapatan negara Indonesia.

$$
\text { Kelebihan Usaha Kecil }
$$

dibandingkan dengan Usaha Besar adalah Inovasi Kebanyakan dalam usaha kecil dan menengah menggunakan strategi tersendiri dengan membuat produk yang unik dan khas untuk menarik pelanggan menggunakan produk dari usaha kecil menengah tersebut. Suatu produk yang ingin dipasarkan harus mempunyai daya tarik bagi pelanggan dan dapat bersaing dengan menengah besar dengan kualitas yang 
dihasilkan produk tersebut dan cara pengelolaan. Penggunaan modal juga tidak terlalu besar dalam usaha kecil menengah. Usaha kecil berhubungan dengan penjual dan pembeli serta usaha kecil menengah ini pun lebih fleksibel dalam barang-barang yang cepat atau kurang laku.

\section{$\underline{\text { Modal UKM }}$}

Dalam menjalankan sebuah usaha, salah satu faktor pendukung yang dibutuhkan adalah modal. Jika kita ibaratkan memulai usaha dengan membangun sebuah rumah, maka adanya modal menjadi bagian pondasi dari rumah yang akan dibangun. Semakin kuat pondasi yang dibuat, maka semakin kokoh pula rumah yang Anda bangun. Begitu juga pengaruh modal terhadap sebuah bisnis, keberadaannya menjadi pondasi awal bisnis yang akan Anda bangun. Beberapa modal yang dibutuhkan dalam menjalankan bisnis, antara lain tekad, pengalaman, keberanian, pengetahuan, networking, serta modal uang atau aset. Namun dari beberapa modal yang dibutuhkan, kebanyakan orang terhambat memulai usaha karena mereka sulit untuk mendapatkan modal uang atau aset.

Ada beberapa alternatif yang dapat digunakan untuk mendapatkan dana usaha, berikut informasi selengkapnya :

1. Dana Sendiri
Pertama bisa memperoleh modal usaha dengan menggunakan dana sendiri. Misalnya saja dengan menggunakan dana simpanan yang sudah tabung selama ini. Jika masih kurang, juga bisa menutupi kekurangan dana tersebut dengan menjual sebagian aset berharga yang miliki saat ini.

2. Mencari Hibah

Cara yang kedua yaitu bisa saja kita manfaatkan dana-dana pihak ketiga, dalam hal ini pihak pemerintah atau pihak swasta. Sebagaimana kita tahu, untuk beberapa perusahaan-perusahaan besar dana hibah ini disalurkan melalui Divisi CSR- nya (Corporate Social Responsibility). Dalam hal ini perusahaan- perusahaan tersebut bisanya memiliki budget atau anggaran dana tersendiri dalam membangun perekonomian masyarakat disekitar perusahaan atau masyarakat secara umum. untuk teknis penyaluran dananya biasanya melalui event-event competition. Oleh karena itu, bisa jadi melalui event-event tersebut dapat menjadi salah satu solusi untuk mendapatkan tambahan dana bagi kelangsungan usaha UKM.

3. Menjalin Kerjasama

Cara yang ketiga ini yang sekarang banyak dijalankan, yaitu menjalin kerjasama dengan pihakpihak tertentu. Seperti bekerja sama dengan teman, atau bisa juga menawarkan kerjasama dengan para investor. Yang perlu diperhatikan dalam menawarkan kerjasama, harus meyakinkan rekan mengenai 
prospek bisnis yang akan dibangun. bisa menggunakan proposal bisnis, untuk meyakinkan calon investor Berikan pula keterangan mengenai berapa persen pembagian hasil antara investor dan pelaku usaha, sehingga kedua belah pihak tidak ada yang merasa dirugikan. Bila perlu buat perjanjian hitam diatas putih, untuk mengantisipasi bila terjadi sesuatu dikemudian hari.

\section{$\underline{\text { Konsep Strategi Pengembangan }}$}

Strategi adalah tujuan jangka panjang dari suatu perusahaan, serta pendayagunaan dan alokasi semua sumber daya yang penting untuk mencapai tujuan tersebut (Chandler,1962:13 dalam Rangkuti ,2002:4). Pemahaman yang baik mengenai konsep strategi dan konsep-konsep lainyang bersangkutan sangat menentukan suksesnya strategi apa yang akandisusun. Konsepkonsep tersebut adalah:

1. Distinctive Competence: tindakan yang dilakukan perusahaan agar dapat melakukan kegiatan lebih baik dibandingkan dengan pesaingnya. Distinctive Competence ini meliputi keahlian tenaga kerja dan kemampuan sumber daya.

2. Competitive Advantage: kegiatan spesifik yang dikembangkan perusahaan untuk melakukan yang lebih baik dibanding dengan pesaingnya. Strategi yang digunakan untuk memperoleh keunggulan dalam bersaing adalah cost leadership, differensial dan focus.

$$
\text { Porter menyebutkan }
$$
competive advantage terbagi menjadi 3 (dalam Rangkuti, 2009: 6) yaitu:

1. Keunggulan biaya menyeluruh (Cost Leadership)

Pencapaian

biaya

keseluruhan yang rendah seringkali menuntut bagian pasar relative yang tinggi atau kelebihan yang lain, seperti akses yang menguntungkan kepada bahan baku. Selain itu juga perlu untuk merancang produk agar mudah didapat, menjual banyak lini produk yang mudah dibuat, menjual banyak lini produk yang berkaitan untuk menebarkan biaya, serta melayani kelompok pelanggan yang besarguna membangun volume. Penerapan strategi biaya rendah mungkin memerlukan investasi modal pendahuluan yang besar untuk peralatan modern, penetapan harga yang agresif dan kerugian awal untuk membina bagian pasar yang tinggi pada akhirnya dapat memungkinkan skala ekonomis dalam pembelian yang akan semakin menekan biaya (Porter,2008: 32).

2. Diferensiasi

Diferensiasi merupakan strategi yang baik untuk menghasilkan laba diatas rata-rata dalam suatu industri karena strategi ini menciptakan posisi yang aman untuk mengatasi kekuatan pesaing, meskipun dengan cara yang berbeda dari strategi keunggulan biaya. Diferensiasi memberikan penyekat kepada persaingan karena adanya 
loyalitas dari merk pelanggan dan mengakibatkan berkurangnya kepekaan terhadap harga. Diferensiasi juga meningkatkan margin laba yang menghindarkan kebutuhan akan posisi biaya rendah (Porter, 2008: 34).

3. Fokus

Strategi biaya rendah dan diferensiasi ditunjukan untuk mencapai sasaran dikeseluruhan industri, maka strategi fokus dibangun untuk melayani target secara baik. Strategi ini didasarkan pada pemikiran bahwa perusahaan dengan demikian akan mampu mel ayani target strateginya yang sempit secara lebih efektif dan efisien dibandingkan dengan pesaing yang bersaing lebih luas.

\section{$\underline{\text { Tipe - Tipe Strategi }}$}

Menurut Rangkuti (2009: 7), Strategi dapat dikelompokan menjadi 3 (tiga) tipe strategi yaitu:

1. Strategi manajemen

Strategi manajemen meliputi strategi yang dapat dilakukan oleh manajemen dengan orientasi pengembangan strategi secara makro, misalnya strategi pengembangan produk, penerapan harga, akuisisi, pengembangan pasar dan sebagainya.

2. Strategi Investasi

Strategi ini merupakan kegiatan yang berorientasi pada investasi, misalnya perusahaan ingin melakukan strategi pertumbuhan yang agresif atau berusaha melakukan penetrasi pasar, strategi bertahan, strategi pembangunan kembali divisi baru dan sebagainya.

3. Strategi bisnis

Strategi ini sering disebut strategi bisnis secara fungsional karena strategi ini berorientasi pada fungsi-fungsi kegiatan manajemen, misalnya strategi pemasaran, produksi atau operasional, distribusi, dan strategi yang berhubungan dengan keuangan.

\section{Analisis SWOT}

\begin{tabular}{lrr}
\multicolumn{1}{c}{ Analisis $\begin{array}{c}\text { SWOT } \\
\text { Inggris }\end{array}$} & (singkatan \\
bahasa dari \\
"kekuatan"/strengths, \\
"kelemahan"/weaknesses, \\
"kesempatan"/opportunities, \\
"ancaman"/threats) adalah & dan \\
perencanaan strategis & yang
\end{tabular}
digunakan untuk mengevaluasi kekuatan, kelemahan, peluang, dan ancaman dalam suatu proyek atau suatu spekulasi bisnis. Proses ini melibatkan penentuan tujuan yang spesifik dari spekulasi bisnis atau proyek dan mengidentifikasi faktor internal dan eksternal yang mendukung danyang tidak dalam mencapai tujuan tersebut (Wikipedia Indonesia,2009). Strength merupakan hal-hal menjadi unggulan atau ciri khas suatu tempat wisata. Weakness merupakan kendala, yakni merupakan hal-hal yang dapat menghambat pengembangan tempat wisata. Opportunity merupakan peluang yakni hal-hal yang dapat dikembangkan lebih lanjut, sedangkan Threats merupakan ancaman, yaitu hal-hal yang dapat 
mengganggu pengembangan tempat wisata (Fanni Winih, 2007 : 25).

Yoeti (1995

memaparkan bagaimana analisis

SWOT dalam sekenario

pengembangan pariwisata adalah sebagai berikut :

1. Kekuatan (Strength)

Mengetahui kekuatan

pariwisata suatu wilayah, maka akan dapat dikembangkan sehingga mampu bertahan dalam pasar dan mampu bersaing untuk pengembangan selanjutnya. Dalam hal ini, kekuatan dapat dimanfaatkan secara maksimal untuk meraih peluang.

2. Kelemahan (Weakness)

Segala faktor yang tidak menguntungkan atau merugikan bagi sector pariwisata. Pada umumnya, kelemahan-kelemahan yang dapat didentifikasi adalah kurangnya promosi, jeleknya pelayanan, kurang profesionalnya pelaksana pariwisata di lapangan, terbatasnya kendaraan umum ke obyek wisata.

3. Kesempatan (Opportunity)

Semua kesempatan yang ada sebagai akibat kebijakan pemerintah, peraturan yang berlaku, atau kondisi perekonomian

4. Ancaman (Threats)

Ancaman dapat berupa halhal yang dapat mendatangkan kerugian bagi pariwisata, seperti peraturan yang tidak memberikan kemudahan dalam berusaha, rusaknya lingkungan, dan lain sebagainya.

Analisis SWOT merupakan sebuah alat analisis yang cukup baik, efektif, dan efisien serta sebagai alat yang cepat dalam menemukan kemungkinan yang berkaitan dengan pengembangan awal program-program inovasi baru dalam kepariwisataan. Sifat analisis SWOT sangat situasional, dalam artian hasil analisis tahun sekarang belum tentu akan sama dengan hasil analisis tahun yang akan datang, pengaruh faktor ekonomi, politik, kemanan dan keadaan soial yang melatarbelakanginya menyebabkan adanya perubahan (Yulita, 2008). Berdasarkan aspek-aspek diatas kemudian dimasukkan dalam matriks analisis. Analsis ini menghasilkan suatu alternatif pengembangan usaha atau menghindari ancaman. Ada dua hal yang mempengaruhi yaitu faktor internal dan eksternal. Internal meliputi kekuatan yang menjadi potensi dan kelemahan yang menjadi kendala, sedangkan eksternal meliputi peluang yang menjadi kesempatan dan tantagan yang menjadi penghambat. Matrik analisis tersebut disajikan di bawah ini:

Faktor InternalPotensi/Kekuatan

(Strength) Kendala/Kelemahan

(Weakness)

Faktor

Eksternal

(Opportunities)

Tantangan/Hambatan

(Threats)

\section{METODOLOGI PENELITIAN}

Penelitian yang digunakan adalah metode kualitatif deskriptif. Metode penelitian kualitatif sering disebut metode penelitian 
naturalistik, karena penelitiannya dilakukan pada kondisi yang alamiah dan sering juga disebut metode interpretive karena data hasil penelitian lebih berkenaan dengan interpretasi data yang ditemukan di lapangan (Sugiyono, 2008 : 330). Penelitian deskriptif adalah penelitian yangberusaha mendeskripsikan dan menginterpretasikan data dengan pengukuran secara obyektif terhadap fenomena yang ada (Singarimbun, 1989:4). Komponen dalam metode penelitian ini adalah tempat dan waktu penelitian, data dan sumber data, instrument penelitian, populasi (situasi sosial), teknik pengumpulan data, pemeriksaan keabsahan data serta teknik analisis data. Lokasi yang dijadikan sebagai tempat penelitian adalah usaha kegitatan kecil dan menengah yang terletak di jalan Ladang dalam RT. 10 No 97A Tempat tersebut adalah tempat kami melakukan penelitian.

\section{Data dan Sumber Data}

\section{Data Primer}

Dalam penelitian ini data diperoleh dari jawaban pemilik UKM Azzahra Trk, wawancara yang disampaikan langsung oleh peneliti. Data tersebut berupa jumlah produksi yang didapatkan sebulan t erakhir dan meminta Informasi permasalahan dan kebijakan usaha amplang Bulan-bulan yang didapatkan dengan wawancara kepada pemilik UKM.

2. Data Sekunder
Data dekunder merupakan sumber data penelitian yang diperoleh peneliti secara tidak langsung melalui media perantara atau diperoleh dan dicatat oleh pihak lain (Indriantoro dan Supomo, 1999). Data tersebut diperoleh dari Badan Pusat Statistik Kota Tarakan, Pengelola amplang ikan bandeng, jurnal ekonomi dan literature lain yang membahas mengenai materi penelitian berupa potensi dan pengembangan usaha amplang bandeng, dan data pendukung lainnya yang dianggap dapat mendukung penelitian ini.

\section{$\underline{\text { Teknik Pengumpulan Data }}$}

Dilihat dari jenis data yang dikumpulkan, dalam penelitian ini meggunakan teknik pengumpulan data Trianggulasi. Dalam teknik pengumpulan data trianggulasi diartikan sebagai teknik pengumpulan data yang menggabungkan dari berbagai teknik dan sumber data yang ada (Sugiyono, 2008:330). Teknikteknik yang digunakan adalah :

1. Survei lapangan / Observasi

Teknik ini sesuai untuk pengumpulan data primer dengan cara langsung melakukan pengamatan di lapangan untuk digabungkan dan dilengkapi data yang didapatkan dari data sekunder. Secara visual pengamatan biasanya dilengkapi dengan kamera dan catatan lapangan. 2. Studi Dokumentasi

Teknik ini sesuai untuk pengumpulan data skunder yang dikumpulkan dari instansi atau lembaga-lembaga yang berkompeten, 
berupa laporan-laporan, jurnal, artikel media dan lain lain yang dipandang relevan dengan penelitian yang dilakukan.

3. Wawancara

Wawancara dilakukan untuk mendapatkan informasi ekternal terkait faktor peluang dan penghambat pengembangan usaha amplang bandeng. Infromasi didapatkan dari informan atau orang yang dianggap tahu tentang hal tersebut. Informan ditentukan dengan purposive snowball sampling. Teknik ini pada awalnya ditentukan sejumlah kecil orang kemudian akan berkembang sesuai dengan kebutuhan data sehingga data yang dikumpulkan lengkap sesuai dengan tujuan penelitian.

\section{$\underline{\text { Alat Analisis }}$}

Alat analisis yang di gunakan adalah alat analisis SWOT.

\section{$\underline{\text { Teknik Analisis Data }}$}

Data diperoleh dari berbagai sumber, dengan menggunakan teknik pengumpulan data trianggulasi, $d$ ata yang diperoleh adalah data kualitatif sehingga diperlukan analisis data.

Analisis data adalah proses mencari dan menyusun secara sistematis data yang diperoleh dari hasil wawancara, catatan lapangan dan dokumentasi, dengan cara mengorganisasikan ke dalam kategori, unit-unit, melakukan sintesa, menyusun ke dalam pola dan memilih yang penting untuk dipelajari, dan membuat kesimpulan sehingga mudah di fahami diri sendiri maupun orang lain (Sugiyono, 2008 : 333 - 335). Teknik analisis data adalah proses penyederhanaan data kedalam bentuk yang lebih mudah (Masri Singarimbun, 1987 : 256).

\section{HASIL DAN PEMBAHASAN}

$\underline{\text { Hasil Analisis SWOT }}$

Pada bagian ini akan di jelaskan tentang analisis SWOT pada UKM pengolahan amplang Azzahra Trk.

\section{$\underline{\text { Tabel Internal Strategi }}$}

\begin{tabular}{|c|c|c|c|}
\hline FAKTOR INTERNAL STRATEGI & $\begin{array}{l}\text { BOBOT } \\
\text { (a) }\end{array}$ & $\begin{array}{l}\text { RATING } \\
\text { (b) }\end{array}$ & $\begin{array}{l}\text { SKOR } \\
\text { TERBOBOT } \\
(\mathrm{axb})\end{array}$ \\
\hline \multicolumn{4}{|l|}{ KEKUATAN / STRENGTH } \\
\hline 1. Rasa yang menarik & 0,15 & 4 & 0,6 \\
\hline 2. Harga yang terjangkau & 0,13 & 4 & 0,52 \\
\hline $\begin{array}{l}\text { 3. Tidak menggunakan bahan } \\
\text { pengawet }\end{array}$ & 0,11 & 3 & 0,33 \\
\hline $\begin{array}{l}\text { 4. Proses produksinya mudah dan } \\
\text { waktunya singkat }\end{array}$ & 0,11 & 3 & 0,33 \\
\hline
\end{tabular}




\begin{tabular}{|l|l|l|l|}
\hline 5. Bahan baku yang mudah diperoleh & 0,05 & 2 & 0,1 \\
6. Tenaga kerja yang ahli & 0,07 & 2 & 0,14 \\
7. Kualitas terjamin & 0,07 & 3 & 0,21 \\
\hline Jumlah & 0,69 & & 2,23 \\
\hline KELEMAHAN / WEAKNESS & & & \\
\hline 1. Minimnya tenaga kerja & 0,15 & 4 & 0,6 \\
2. Manajemen tradisional & 0,03 & 2 & 0,06 \\
3. Sarana dan Prasarana sederhana & 0,13 & 3 & 0,39 \\
\hline Jumlah & 0,31 & & 1,05 \\
\hline TOTAL & 1 & & 3,28 \\
\hline
\end{tabular}

Sumber : hasil pengelola data, 2017

$\underline{\text { Tabel Eksternal Strategi }}$

\begin{tabular}{|c|c|c|c|}
\hline FAKTOR EXTERNAL STRATEGI & $\begin{array}{l}\text { BOBOT } \\
\text { (a) }\end{array}$ & $\begin{array}{l}\text { RATING } \\
\text { (b) }\end{array}$ & $\begin{array}{l}\text { SKOR } \\
\text { TERBOBOT } \\
(\mathrm{axb})\end{array}$ \\
\hline \multicolumn{4}{|l|}{ PELUANG / OPPORTUNITIES } \\
\hline 1. Prospek pasar yang menjanjikan & 0,16 & 4 & 0,64 \\
\hline $\begin{array}{l}\text { 2. Hubungan kerjasama dan dukungan } \\
\text { pemerintah }\end{array}$ & 0,16 & 4 & 0,64 \\
\hline $\begin{array}{l}\text { 3. Peningkatan kreatifitas produk } \\
\text { dimasa yang akan datang }\end{array}$ & 0,15 & 4 & 0,6 \\
\hline $\begin{array}{l}\text { 4. Perkembangan teknologi informasi } \\
\text { dalam promosi produk }\end{array}$ & 0,16 & 3 & 0,48 \\
\hline Jumlah & 0,63 & & 1,28 \\
\hline \multicolumn{4}{|l|}{ KELEMAHAN / WEAKNESS } \\
\hline 1. Munculnya pesaing baru & 0,09 & 3 & 0,27 \\
\hline $\begin{array}{l}\text { 2. Munculnya variasi makanan } \\
\text { jajanan }\end{array}$ & 0,15 & 3 & 0,45 \\
\hline $\begin{array}{l}\text { 3. Tenaga kerja yang masih rendah } \\
\text { pendidikan }\end{array}$ & 0,13 & 2 & 0,26 \\
\hline Jumlah & 0,37 & & 0,98 \\
\hline TOTAL & 1 & & 2,26 \\
\hline
\end{tabular}

Sumber : hasil pengelola data, 2017

Keterangan angka :

1. Bobot

$>0,04 \quad$ sangat tidak penting

$0,05-0,08$ tidak penting

$0,09-0,12$ cukup penting

$0,13-0,16$ penting sekali
2. Rating

Pada S dan O Pada W dan T

2 (kurang) 1 (kurang)

3 (cukup) 2 (cukup)

4 (penting) 3 (penting) 
Dari hasil perhitungan pada perbandingan antara kekuatan dan kelemahan pada tabel IFAS dan EFAS antara peluang dan ancaman pada Tabel EFAS di ketahui jumlah sebagai berikut :

Kekuatan (S) $\quad: 2,23$

Kelemahan (W) $\quad: 1,05$

Peluang $(\mathrm{O}) \quad: 1,28$

Ancaman $(\mathrm{T}) \quad: 0,98$
Dapat dilihat bahwa pada hasil perhitungan IFAS S (2.23) > W (1.05) sementara pada hasil perhitungan EFAS O (1.28) > T (0.98). sehingga jelas UKM azzahra Trk harus memilih dan menggunakan strategi agresif atau berkembang, dimana mencaku p kondisi kekuatan dan peluang berar pada posisi yang baik (Strategi SO).

Tabel IFAS (Internal Factors Analysis Summary) dan EFAS (External Factors Analysis Summary)

\begin{tabular}{|c|c|c|}
\hline Internal Factor & $\begin{array}{ll} & \text { Kekuatan (S) } \\
\text { 1. Rasa yang menarik } \\
\text { 2. Kualitas terjamin } \\
\text { 3. Tidak menggunakan } \\
\text { bahan pengawet } \\
\text { 4. Proses produksinya } \\
\text { mudah daan tidak } \\
\text { membutuhkan waktu } \\
\text { yang lama } \\
\text { 5. Bahan baku yang } \\
\text { mudah diperoleh } \\
\text { 6. Tenaga kerja yang } \\
\text { ahli } \\
\text { 7. Harga Terjangkau }\end{array}$ & $\begin{array}{ll}\text { Kelemahan }(\mathrm{W}) \\
\text { 1. } \\
\text { Minimnya tenaga } \\
\text { kerja } \\
\text { 2. } \text { Manajemen } \\
\text { tradisional } \\
\text { 3. } \begin{array}{l}\text { Sarana dan prasarana } \\
\text { Sederhana }\end{array}\end{array}$ \\
\hline \begin{tabular}{ll}
\multicolumn{1}{c}{ Peluang $(\mathrm{O})$} \\
1. & Prospek pasar yang \\
2. & Menjanjikan \\
3. & Hubungan kerjasama \\
& dan dukungan \\
pemerintah \\
4. Kekreatifitasan \\
produk di masa yang \\
akan dating \\
5. Perkembangan \\
tekhnologi dan \\
informasi
\end{tabular} & $\begin{array}{l}\text { Strategi (WO) } \\
\text { 1. Proses yang mudah, } \\
\text { tidak membutuhkan } \\
\text { waktu lama dan } \\
\text { bahan mudah di } \\
\text { peroleh dapat } \\
\text { menyediakan } \\
\text { permintaan produk di } \\
\text { pasar } \\
\text { 2. Produk yang } \\
\text { ekonomis dan } \\
\text { terjamin menciptakan } \\
\text { peluang dalam }\end{array}$ & $\begin{array}{l}\text { Strategi (WO) } \\
\text { 1. Adanya kerjasama } \\
\text { dan dukungan } \\
\text { pemerintah dapat } \\
\text { memperbaharui } \\
\text { sarana dan prasarana } \\
\text { yang sederhana. } \\
\text { 2. Besarnya permintaan } \\
\text { akan produk dapat } \\
\text { membuka lowongan } \\
\text { pekerjaan. }\end{array}$ \\
\hline
\end{tabular}




\begin{tabular}{|c|c|c|}
\hline & $\begin{array}{l}\text { kerjasama, perijinan } \\
\text { dan dukungan } \\
\text { pemerintah } \\
\text { 3. Pemanfaatan tenaga } \\
\text { kerja ahli dapat } \\
\text { menciptakan inovasi } \\
\text { baru akan produk. }\end{array}$ & \\
\hline $\begin{array}{l}\text { Ancaman (T) } \\
\text { 1. Munculnya pesaing } \\
\text { Baru. } \\
\text { 2. Munculnya Variasi } \\
\text { makanan jajanan. } \\
\text { 3. Tenaga kerja yang } \\
\text { masih rendah } \\
\text { pendidikan. }\end{array}$ & 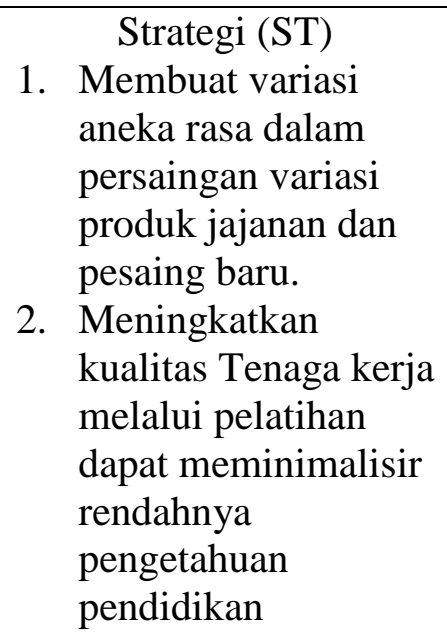 & $\begin{array}{l}\text { Strategi (WT) } \\
\text { 1. } \begin{array}{l}\text { Meningkatkan } \\
\text { kualitas sarana } \\
\text { prasarana. }\end{array} \\
\text { 2. Adanya pembinaan } \\
\text { tenaga kerja. } \\
\text { 3. Menciptakan } \\
\text { inovasi baru }\end{array}$ \\
\hline
\end{tabular}

\begin{tabular}{|c|c|c|}
\hline Strategi & Nilai & Pilihan Strategi \\
\hline Berkembang & $\mathrm{S}>\mathrm{O}$ & Pertumbuhan Cepat \\
\hline & $\mathrm{S}<\mathrm{O}$ & Pertumbuhan Stabil \\
\hline Bertahan & $\mathrm{W}>\mathrm{T}$ & Berbenah Diri \\
\hline Diserfikasi & $\mathrm{W}<\mathrm{T}$ & Gerilya \\
\hline & $\mathrm{S}>\mathrm{T}$ & Konglomerat \\
\hline Stabil & $\mathrm{S}<\mathrm{T}$ & Konsentrik \\
\hline & $\mathrm{W}>\mathrm{O}$ & Pemeliharaan Agresif \\
\hline & $\mathrm{W}<\mathrm{O}$ & Pemeliharaan Selektif \\
\hline
\end{tabular}

Berdasarkan analisa dari tabel menyebutkan bahwa, UKM azzahra dalam strategi pengembangannya seharusnya memilih strategi berkembang, dimana kekuatan (S) lebih besar daripada peluang (O), artinya pilihan strateginya berdasarkan tabel pilihan strategi diatas, maka pilihan strateginya adalah pertumbuhan cepat dengan pemanfaatan kekuatan dan peluang yang dimiliki oleh produk amplang 
bulan-bulan. Adapun cara yang apat dilakukan oleh UKM Azzahra Trk dalam pengembangannya sebagai berikut :

1. Produk amplang bulan-bulan UKM Azzahra Trk memiliki rasa yang menarik. Ini merupakan potensi yang dapat terus di kembangkan oleh UKM Azzahra Trk.

2. Bahan yang mudah di peroleh menjadi kemudahan dalam memproduksi barang dalam jumlah banyak.

3. UKM Azzahra Trk memiliki tenaga kerja yang ahli dalam memproduksi, hal ini merupakan potensi dalam penciptaan olahan produk yang lebih menarik.

4. Melakukan penambahan cabang UKM Amplang Bulan-bulan di luar daerah dalam memperluas penyebaran produk.

\section{PEMBAHASAN}

Berikut pembahasan dari hasil analisis SWOT UKM Azzahra Trk :

\section{$\underline{\text { Strength (Kekuatan) }}$}

1. Produk yang memiliki rasa menarik. UKM Azzahra Trk merupakan salah satu UKM yang memproduksi amplang bulan-bulan di daerah Tarakan. Dalam memproduksi amplang bulan-bulan produsen memiliki resep khusus yang membuat rasa amplang tersebut menjadi menarik dan banyak di nikmati masyarakat.
2. Produk yang terjamin menjadikan produk dapat di percaya masyarakat banyak.

3. Produk tidak menggunakan bahan pengawet sangat aman untuk di konsumsi.

4. Proses produksi yang mudah dan tidak membutuhkan waktu lama memudahkan dalam menerima permintaan produk pasar yang banyak.

5. Berada di kawasan yang strategis memudahkan produsen dalam memperoleh penyedian bahan baku pembuatan amplang.

6. Tenaga kerja yang ahli memudahkan dalam proses produksi.

7. Harga terjangkau menjadi kekuatan dalam penjualan dan menambah daya beli masyarakat Tarakan dan sekitarnya karena harga yang terjangkau.

Weakness (Kelemahan)

1. Minimnya tenaga kerja. UKM Azzahra Trk ini minim tenaga kerja karena hanya memiliki 8 tenaga kerja yang bekerja.

2. Manajemen tradisional. Menejemen perusahaan masih menggunakan manajemn tradisional karena pemilik dan pekerja masih dalam kalangan keluarga.

3. Sarana dan prasarana yang masih sederhana. Sarana dan sarana yang masih terbilang kurang dan sederhana dan belum menggunakan teknologi yang modern. 


\section{Opportunities (Peluang)}

1. Prospek pasar yang menjanjikan. Penyebaran Penjualan produk yang sudah meluas di daerah Tarakan dari toko-toko kecil sampai super market dan penjualan produk meluas sampai keluar kota.

2. Hubungan kerjasama dan dukungan pemerintah. Adanya hubungan kerjasama pemerintah memudahkan dalam perijnan dan bantuan sarana dan prasarana serta memudahkan perkembangan UKM dan produk.

3. Kekreatifitasan produk di masa yang akan datang. Menciptakan inovasi produk baru dari rasa, tekstur, warna dan kemasan untuk meningkatkan daya saing di masa yang akan datang.

4. Perkembangan teknologi dan informasi. Berkembangnya teknologi yang lebih modern memudahkan dalam mempercepat produksi dan pemasaran yang mudah karena menggunakan media sosial.

\section{Threats (Ancaman)}

1. Munculnya pesaing baru. Seprti yang kita ketahui dimasa sekarang in UKM pengolahan ikan khususnya Amplang semakin bertambah banyak dan bertumbuh pesat, hal ini merupakan ancaman bagi UKM Azzahra Trk.

2. Munculnya Variasi makanan jajanan. Seiring perkembangan zaman semakin berkembangnya juga varasi makanan ringan yang akan menjad pesaing produk dan ancaman produk UKM Azzahra Trk.

3. Tenaga kerja yang masih rendah pendidikan. Rendahnya pendidikan tenaga kerja dapat menjadi ancaman untuk perkembangan produk amplang. Hal ini karena kurangnya pengetahuan dan inovasi baru dari perkembangan produk.

\section{KESIMPULAN DAN SARAN}

\section{$\underline{\text { Kesimpulan }}$}

Dari hasil penelitian tersebut, dapat di ambiL kesimpulan tentang penerapan SWOT pada UKM Azzahra Trk Ampalang Buan-bulan sebagai berikut :

1. Penerapan analisis SWOT pada produk Amplang Bulan-bulan Menggunakan analisis faktor Internal dan Eksternal Strategi.

2. Dari hasil analisa di atas Menyebutkan bahwa, produk amplang bulan-bulan UKM Azzahra Trk dalam strategi perkembangannya seharusnya menggunakan Strategi Berkembang. Artinya, kekuatan (S) lebih besar dari pada pluang (O), artinya pilihan strateginya adalah pertumbuhan cepat dengan memanfaatkan kekuatan dan peluang yang dimiliki oleh produk amplang bulan-bulan UKM Azzahra Trk.

3. Hasil perhitungan pada perbandingan antara kekuatan dan kelemahan pada tabel IFAS dan 
EFAS, perhitungan IFAS menunjukan bahwa Strenght (S) lebih besar dari Weaknes (W). Sementara perhitungan EFAS menunjukkan Opportunity (O) lebih besar dari Threathnes $(\mathrm{T})$.

4. Dari analisa yang sudah diakukan, UKM Azzahra Trk harus memilih dan menggunakan strategi agresif atau berkembang, dimana mencakup kondisi kekuatan dan peluang berada pada posisi yang baik (strategi $\mathrm{SO}$ ).

$\underline{\text { Saran }}$

beberapa saran yang dapat dikemukakan sebagai berikut :

1. Bagi peneliti, perlu ada kajian yang lebih komprehensif terkait dengan pengembangan produk amplang karena UKM Azzahra Trk memiliki potensi yang bisa di optimalkan.

2. Bagi pengusaha, bagi UKM Azzahra Trk perlu mempertimbangkan hasil penelitian ini dalam kerangka pengembangan. Memanfaatkan perkembangan teknologi dan informasi yang semakin menjamur di Kota Tarakan.

\section{DAFTAR PUSTAKA}

Rangkuti, Fredy. 1997. Analisis SWOT Teknik Membedah Kasus Bisnis. PT. Gramedia Pustaka Utama, Jakarta.
Anonim, 2009. Analisis SWOT. http://id.wikipedia.org/wiki/An alisis_SWOT. diakses Senin, 19 Oktober 2009.

Afiffudin MM. Metodologi Peneliti Kualitatif Bandung. CV Pustaka Setia Damardjati, R.S

Fred David (2011). Strategic Management Concepts and Cases, 13th Edition. New Jersey. Prentice Hall.

Umar H. 2000. Studi Kelayakan Bisnis. Jakarta: PT Gramedia Pustaka Utama 
